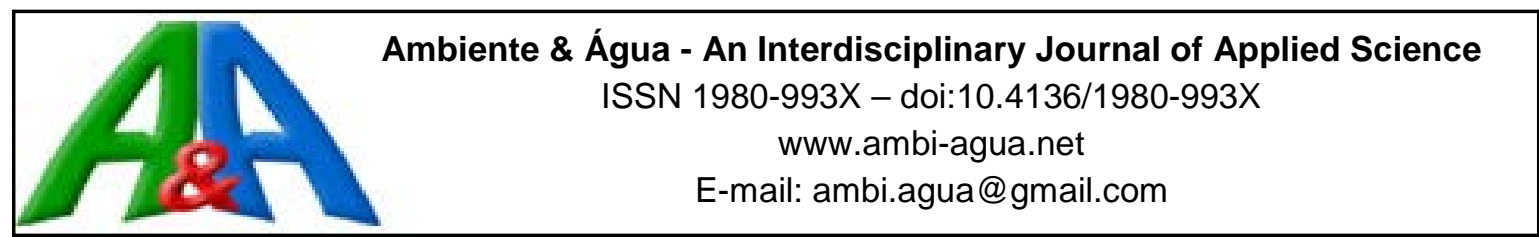

\title{
Bioaccumulation of heavy metals in Oncorhynchus mykiss for export at production centers in the Peruvian Central Highlands
}

\author{
doi:10.4136/ambi-agua.2100
}

Received: 21 Feb. 2017; Accepted: 01 Jun. 2017

\author{
Fernán Cosme Chanamé Zapata*; María Custodio Villanueva; \\ Rafael Antonio Pantoja Esquivel; Ide Gelmore Unchupaico Payano \\ Universidad Nacional del Centro del Perú (UNCP), Huancayo, Junín, Perú \\ Facultad de Zootecnia \\ *Corresponding author: e-mail: fernan_chz@hotmail.com, \\ mcustodio@uncp.edu.pe,centrozoot@hotmail.com,ide_85@hotmail.com
}

\begin{abstract}
The bioaccumulation of the heavy metals $\mathrm{Cu}, \mathrm{Zn}, \mathrm{Fe}$ and $\mathrm{Pb}$ was determined in the livers, kidneys and muscles of Oncorhynchus mykiss trout at seven production centers in the province of Yauli, Junín-Peru. The determination and quantification of total heavy metals in water samples collected monthly from the production sites and in 28 trout that averaged $250 \mathrm{~g}$ and $27 \mathrm{~cm}$ was performed by atomic absorption spectrophotometry, according to the methodology recommended by FAO. Levels of $\mathrm{Zn}, \mathrm{Fe}$ and $\mathrm{Pb}$ were found to exceed the environmental quality standards established by the Peruvian Ministry of the Environment for the rivers of the coast and highlands, as well as the quality standards of the European Union for the cultivation of trout, while levels of $\mathrm{Cu}$ conformed with those standards. Concentration of $\mathrm{Cu}, \mathrm{Zn}, \mathrm{Fe}$ and $\mathrm{Pb}$ in the livers, kidneys and muscles exceeded the maximum permissible limits established by the European Union for fish meat and by the Mexican official standard, NOM-027-SSA1-1993, for fresh, refrigerated and frozen fishery products, in the case of Pb. The correlation between the concentrations of copper, zinc, iron and lead in the water and the concentrations of these metals in the livers, kidneys and muscles is low and not significant, except for copper, which had a significant correlation.
\end{abstract}

Keywords: atomic absorption spectrophotometry, bioaccumulation, heavy metals, trout.

\section{Bioacumulação de metais pesados em Oncorhynchus mykiss para exportação dos centros de produção dos Andes Centrais do Peru}

\section{RESUMO}

A bioacumulação de metais pesados de $\mathrm{Cu}, \mathrm{Zn}, \mathrm{Fe}$ e $\mathrm{Pb}$ no fígado, rim e músculo da truta Oncorhynchus mykiss foi determinada em sete centros de produção na província de Yauli, Junín-Peru. A determinação e quantificação do total de metais pesados em amostras de água coletadas mensalmente nos locais de produção e em 28 trutas de 250 g e $27 \mathrm{~cm}$ em média foram realizadas por espectrofotometria de absorção atômica, de acordo com a metodologia recomendada pela FAO. Com exceção do $\mathrm{Cu}$, alguns níveis de $\mathrm{Zn}$, Fe e $\mathrm{Pb}$ foram encontrados na água em padrões de qualidade ambiental superiores aos estabelecidos pelo Ministério do Meio Ambiente do Peru para os rios do litoral e planalto, e aos padrões de qualidade da União 
Europeia para o cultivo da truta. A concentração de $\mathrm{Cu}$, Zn, Fe e $\mathrm{Pb}$ no fígado, nos rins e nos músculos excedeu os limites máximos permitidos pela União Europeia para a carne de peixe; e pela NOM-027-SSA1-1993 mexicana para os produtos frescos da pesca, refrigerados e congelados, no caso de $\mathrm{Pb}$. A correlação entre a concentração de cobre, zinco, ferro e chumbo em água e a concentração destes metais no fígado, rim e no músculo, é baixa e não significativa, exceto para cobre que teve correlação significativa.

Palavras-chave: bioacumulação, espectrofotometria de absorção atômica, metais pesados, truta.

\section{INTRODUCTION}

Fish have been recognized as an integral component of a well-balanced diet, and provide an important source of energy, high quality proteins, vitamins and a wide range of other nutrients (Pieniak et al., 2010), such as Omega-3 polyunsaturated fatty acids, whose health benefits have been widely recognized (Swanson et al., 2012; Olmedo et al., 2013). In contrast to these benefits, the frequent presence of chemical pollutants in farmed fish is of great concern (Demirak et al., 2006; Martorell et al., 2011).

The balance of aquatic ecosystems has been altered by increased discharges of organic and inorganic pollutants (Dudgeon et al., 2006; Rizzo et al., 2010), and of these, the heavy metals are among the most worrisome.

Heavy metal pollution resulting from mining activity and increasing industrialization (Lozano et al., 2010) represents a special environmental risk due to its long-term persistence in nature and possible bioaccumulation and biomagnification in the trophic chain (Agah et al. 2009; Kehrig et al., 2009, Lajeunesse et al., 2011, Zenker et al., 2014).

Metals such as copper (Cu), zinc (Zn), cobalt (Co) and iron (Fe) are considered a hazard to the aquatic biota unless they reach concentrations higher than those required for growth and reproduction (Canli and Atli, 2003). However, cadmium (Cd), mercury (Hg) and lead (Pb) present in wastewater discharged in rivers by mineral concentrators in the highlands (Padilla, 2005; Hurtado et al., 2006) has significant adverse effects for the aquatic biota and for human beings (Jiménez et al., 2000; Gammons et al., 2006; Kojadinovic et al., 2007).

The discharge of heavy metals in the Mantaro River watershed, Junin Region, Peru, as a result of mining and metallurgical activities, especially in La Oroya-Yauli, is seriously degrading water quality and species diversity due to its toxicity, persistence and cumulative behavior (García Cambero, 2002; Bandowe et al., 2014). Despite this, the production of rainbow trout in this watershed for export to United States and European markets has increased.

Due to the limited knowledge available on the concentration of heavy metals in the water and rainbow trout of highland ecosystems, more information is needed regarding pollution levels in the waters and rainbow trout specimens of Yauli province production centers. Therefore, the objectives of the study were: (a) to determine the level of accumulation of copper, zinc, iron and lead in livers, kidneys and muscles of trout of commercial size and weight (28 cm and $250 \mathrm{~g}$ on average) and (b) to determine the concentrations of copper, zinc, iron and lead in the water of the production centers.

\section{MATERIAL AND METHODS}

\subsection{Study area}

The study area included the production centers of rainbow trout for export located in the micro watershed of the Huari and Tishgo Rivers, tributaries of the Mantaro River, in the Huari, Casaracra and Paccha Districts of Yauli Province, Junín Region. The "El Paraiso" (CP1) and 
"El Pedregal" (CP2) production centers are located in the district of Huari at 3670 masl (409735E, 8713106N) and at 3654 masl (410467E, 8712942N), respectively. The "Sol Radiante" (CP3) center at 3856 masl (398175E, 8735716N), "Manantial Agua de Vida" (CP4) at 3853 masl (398038E, 8735583N), "Contratistas Véliz" (CP5) at 3845 masl (397549 E, 8735250N) and Eloim (CP6) at 3842 masl (397159E, 8734904N) are located in the district of Casaracra and the "Casaracra" (CP7) production center at 3801 masl (396041E, 8733599N) in the district of Paccha (396041E, 8733599N). (Figure 1).

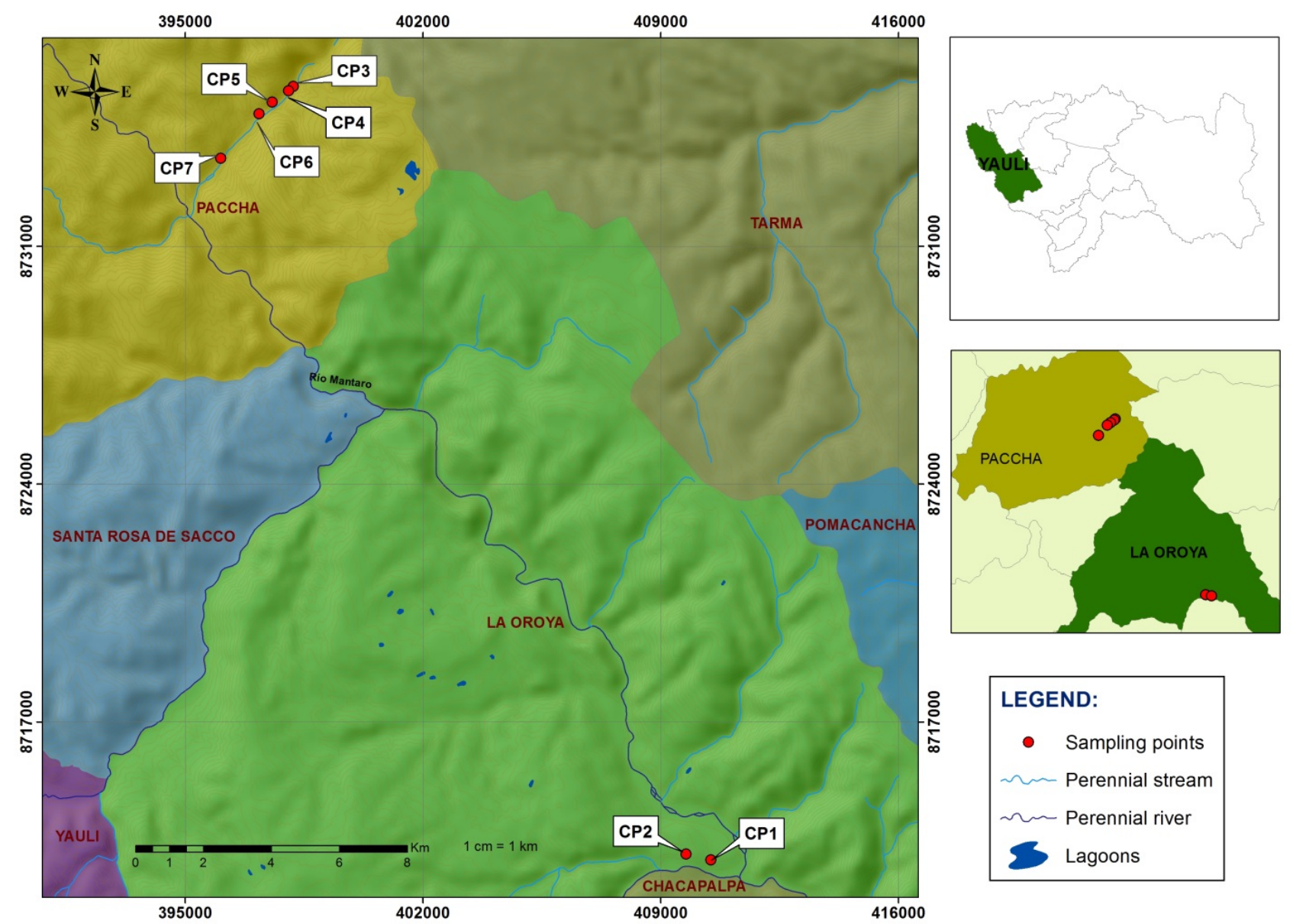

Figure 1. Location of production centers of rainbow trout for export (CP) in the Huari and Tishgo Rivers, Mantaro River Watershed.

\subsection{Methods}

\subsubsection{Determination of heavy metals in livers, kidneys, and muscles}

A total of 28 trout that averaged $250 \mathrm{~g}$ and $27 \mathrm{~cm}$ were collected from seven production centers in the province of Yauli. These were transported in dry ice the same day of their capture to the Laboratory of Instrumental Analysis of the Faculty of Chemical Engineering of the Universidad Nacional del Centro del Peru for chemical analysis. The next day the livers, kidneys and dorsal muscles were separated from each fish. Ten g of each tissue were weighed into a porcelain capsule and calcined on a heating plate. Subsequently, the capsules were placed in the muffle for the destruction of organic matter at $500^{\circ} \mathrm{C}$ for three hours. For the preparation of the sample, the ash was dissolved with a solution of $6 \%$ nitric acid and $3 \%$ hydrochloric acid at a ratio of 1: 1, filtered and diluted in a 100-ml dilution flask with 1\% nitric acid (Dybern et al., 1983). The samples were analyzed for three days. 


\subsubsection{Determination of heavy metals in water used for the production of trout}

The water samples were collected in disposable $1.5 \mathrm{~L}$ plastic bottles, previously treated with $10 \%$ nitric acid solution for 24 hours and rinsed with bi-distilled water. $1.5 \mathrm{~mL}$ of concentrated nitric acid was then added to one liter of water from each of the samples to preserve them (APHA, 2012). In addition, temperature, dissolved oxygen and $\mathrm{pH}$ were determined in situ by Hanna Instruments portable equipment (HI 991301 Microprocessor pH / temperature and HI 9146 Microprocessor dissolved oxygen) and portable computers. The equipment had previously been calibrated in the respective sampling sector.

The next day the sample was prepared by placing $250 \mathrm{~mL}$ of water in a beaker which was brought to boiling, until $100 \mathrm{~mL}$ remained. Immediately, $5 \mathrm{~mL}$ of nitric acid and $5 \mathrm{~mL}$ of concentrated hydrochloric acid were added to destroy organic matter and the sample was boiled again until the water achieved a pasty consistency. The sample was allowed to cool and then $10 \mathrm{~mL}$ of distilled water was added, filtered and diluted in a 100-mL dilution flask with 1\% nitric acid (APHA, 2012). The samples were analyzed for one day.

The quantitative determination of heavy metals (copper, zinc, iron and lead) was performed by the flame atomic absorption spectrophotometry method, according to the methodology recommended by Dybern et al. (1983), using a Shimadzu-brand AA-6800 Atomic Absorption Spectrophotometer. Standard solutions of copper, zinc, iron and lead were previously prepared and read in increasing order of concentration to determine the calibration curve, and then the samples readings were done.

\subsubsection{Analysis of data}

Data were expressed as the mean \pm standard deviation and, in order to compare the concentration level of metals present in the water and trout tissues between production centers, were subjected to analysis of variance (ANOVA) with the SPSS 21 program. To determine significant differences between averages, the Tukey's multiple comparisons test was applied with a 5\% error. Also, a correlation analysis was performed between the concentration of metals in water and in the trout tissues, using the linear correlation coefficient (Clifford y Taylor, 2008).

\subsubsection{Elaboration of the calibration curve}

With the standard $1000 \mathrm{ppm}$ of $\mathrm{Pb}, \mathrm{Cu}, \mathrm{Fe}, \mathrm{Zn}$, As; an average standard of $100 \mathrm{ppm}$ concentration was prepared. Then, working standards of 0.001 were prepared; $0.01,0.1,1.0$ and $2.0 \mathrm{ppm}$, with nitric acid at 1\%. The absorbance readings of the standards were then performed at different wavelengths for each element in the atomic absorption spectrophotometer. Finally, the calibration curve was plotted: concentration vs absorbance and the concentration of the samples was read using the respective calibration curve in the atomic absorption spectrophotometer.

\section{RESULTS AND DISCUSSION}

\subsection{Concentration of heavy metals in trout tissues}

When analyzing the average concentrations of copper, zinc, iron and lead in the livers, kidneys and muscles of trout obtained from the production centers of the province of Yauli-Junín, high levels of these metals were registered, which exceeded the maximum permissible limits established by the current international legislation, mainly for muscle. These results are supported by Cuéllar Carrasco (2000), who report that the presence of metals in water facilitates their accumulation in the livers and muscles of fish. The kidneys were also exposed to water metals because blood flows from the gills to the carotid artery, which supplies blood to the kidney. Likewise, the results are corroborated by Jezierska and Witeska (2006), 
who point out that metals accumulate in the bodies of fish in different quantities, due to the different affinities of the metals with the tissues of the fish, at different rates of uptake, deposition and excretion. However, they considered that the accumulation of metals in fish depends on pollution, and may differ for different species of fish that live in the same body of water.

\subsection{Heavy metals in liver}

The mean concentration of heavy metals in trout livers (Table 1) showed considerable oscillations between production centers. For copper, the lowest concentration was observed in CP4 and the highest in CP5, with values of $2.55 \pm 0.23$ and $17.55 \pm 14.33 \mu \mathrm{g} / \mathrm{g}$, respectively, with significant statistical differences $(\mathrm{p} \geq 0.05)$ between production centers. In the case of zinc, the lowest concentration was found in CP7 and the highest in CP1, with values of $12.77 \pm 1.53$ and $38.12 \pm 22.30 \mathrm{ug} / \mathrm{g}$, respectively, with significant statistical differences $(\mathrm{p} \geq 0.05)$ between production centers. For iron, the lowest concentration was observed in CP7 and the highest in $\mathrm{CP} 1$, with values of $33.58 \pm 5.85$ and $111.78 \pm 22.06 \mu \mathrm{g} / \mathrm{g}$, respectively, with statistically significant differences $(\mathrm{p} \geq 0.05)$ between production centers. In the case of lead, the lowest concentration was found in CP6 and the highest in CP1, with values of $1.41 \pm 0.34$ and $6.11 \pm 3.92 \mu \mathrm{g} / \mathrm{g}$, respectively, with no significant statistical differences $(\mathrm{p} \geq 0.05$ ) between production centers.

The liver was the organ that accumulated the highest concentration of heavy metals, concentrated mostly iron, followed by zinc, copper and lead. Copper was basically accumulated in the liver, although levels of it were also detected in the kidneys and a little in the muscles. In a study by Robinson and Avenant-Oldewage (1997) in Tilapia mossambica, it was observed that the liver accumulated the largest amount of copper with respect to other organs, indicating that this high concentration of copper is attributable to the union of this metal with the metallothioneins to form complexes as detoxification mechanisms.

There are studies on the bioaccumulation of copper, zinc, iron and lead in the livers of freshwater fish (García Cambero, 2002), that report a copper concentration of 18.47 to $22.61 \mu \mathrm{g} / \mathrm{g}$ for the "barbo" (Barbus barbus), and a concentration ranging from 20.88 to $27.79 \mu \mathrm{g} / \mathrm{g}$ for zinc. These results are similar to those found in this work. In relation to lead, the content varied from 0.07 to $0.15 \mu \mathrm{g} / \mathrm{g}$. These results are very low in relation to those obtained in this study.

Table 1. Mean concentration of heavy metals in trout livers.

\begin{tabular}{|c|c|c|c|c|c|c|c|}
\hline \multirow{2}{*}{$\begin{array}{l}\text { Metals } \\
\text { ( } \mu \mathrm{g} / \mathrm{g} \text { wet } \\
\text { weight) }\end{array}$} & \multicolumn{7}{|c|}{ Production Center } \\
\hline & CP1 & $\mathrm{CP} 2$ & CP3 & $\mathrm{CP} 4$ & CP5 & CP6 & CP7 \\
\hline Copper & $12.10 \pm 4.63 \mathbf{a}$ & $5.22 \pm 1.48 \mathbf{b}$ & $9.43 \pm 6.16 \mathbf{a}$ & $2.55 \pm 0.23 \mathbf{b}$ & $17.55 \pm 14.33 \mathbf{a}$ & $10.48 \pm 7.00 \mathbf{a}$ & $14.57 \pm 9.18 \mathbf{a}$ \\
\hline Zinc & $38.12 \pm 22.30 \mathbf{a}$ & $29.31 \pm 10.23 \mathbf{a}$ & $29.09 \pm 11.75 \mathbf{a}$ & $16.64 \pm 5.44 \mathbf{b}$ & $29.26 \pm 5.86 \mathbf{a}$ & $18.90 \pm 2.49 \mathbf{b}$ & $12.77 \pm 1.53 \mathbf{b}$ \\
\hline Iron & $111.78 \pm 22.06 \mathbf{a}$ & $73.98 \pm 23.28 \mathbf{b}$ & $40.45 \pm 5.35 \mathbf{b}$ & $37.91 \pm 13.08 \mathbf{b}$ & $76.32 \pm 34.39 a$ & $40.73 \pm 2.21 \mathbf{b}$ & $33.58 \pm 5.85 \mathbf{b}$ \\
\hline Lead & $6.11 \pm 3.92 \mathbf{a}$ & $3.54 \pm 0.85 \mathbf{a}$ & $5.17 \pm 3.83 \mathbf{a}$ & $1.78 \pm 0.43 \mathbf{a}$ & $4.04 \pm 2.18 \mathrm{a}$ & $1.41 \pm 0.34 \mathbf{a}$ & $2.18 \pm 1.14 \mathbf{a}$ \\
\hline
\end{tabular}

Note: Unequal letters in horizontal form, show that there are significant statistical differences between mean concentrations ( $\mathrm{p} \geq 0.05)$. 


\subsection{Heavy metals in kidneys}

The mean concentration of heavy metals in trout kidneys (Table 2) showed fluctuations between production centers. For copper, the lowest concentration was recorded at CP6 and the highest concentration was recorded at CP2, with values of $1.54 \pm 0.80$ and $4.74 \pm 2.45 \mu \mathrm{g} / \mathrm{g}$, respectively, with no statistically significant differences $(\mathrm{p} \geq 0.05)$ between production centers. In the case of zinc, the lowest concentration was registered at CP6 and the highest was registered at CP1, with values of $15.30 \pm 4.47$ and $32.53 \pm 18.10$, respectively, and there were no significant statistical differences $(\mathrm{p} \geq 0.05)$ between production centers. For iron, the lowest concentration was recorded at CP4, and the highest concentration was registered at CP1, with values of $37.33 \pm 9.20$ and $108.02 \pm 51.55 \mu \mathrm{g} / \mathrm{g}$, respectively, with significant statistical differences $(p \geq 0.05)$ between production centers. In the case of lead, the lowest concentration was recorded at CP5 and the highest was registered in CP2, with values of $2.35 \pm 0.41$ and $5.98 \pm 4.50 \mu \mathrm{g} / \mathrm{g}$, respectively, with no significant statistical differences ( $\mathrm{p} \geq 0.05$ ) between production centers.

Regarding the accumulation of heavy metals in the kidneys, this organ mostly concentrated iron, followed by zinc, lead and copper. There are reports of research on the bioaccumulation of copper, zinc and iron in the kidneys of freshwater fish, such as the one made by García Cambero (2002) for the "barbo" (Barbus barbus), which found a concentration of copper in the kidneys that varied from 1.52 to $2.05 \mu \mathrm{g} / \mathrm{g}$, and a concentration of 15.17 to $17.28 \mu \mathrm{g} / \mathrm{g}$ for zinc. These results are lower than those found in this work. As to the content of lead in kidney, a concentration of 0.05 to $0.07 \mu \mathrm{g} / \mathrm{g}$ was found; these concentrations are very low in comparison with those found in this work.

Table 2. Mean concentration of heavy metals in trout kidneys.

\begin{tabular}{lccccccc}
\hline \multirow{7}{*}{$\begin{array}{l}\text { Metals } \\
\begin{array}{l}\mu \mathrm{g} / \mathrm{g} \text { Wet } \\
\text { weigh) }\end{array}\end{array}$} & CP1 & CP2 & CP3 & CP4 & CP5 & CP6 & CP7 \\
\cline { 2 - 8 } Copper & $4.23 \pm 2.31 \mathbf{a}$ & $4.74 \pm 2.45 \mathbf{a}$ & $2.64 \pm 0.99 \mathbf{a}$ & $2.34 \pm 1.56 \mathbf{a}$ & $1.98 \pm 0.86 \mathbf{a}$ & $1.54 \pm 0.80 \mathbf{a}$ & $1.64 \pm 0.81 \mathbf{a}$ \\
Zinc & $32.53 \pm 18.10 \mathbf{a}$ & $28.17 \pm 2.81 \mathbf{a}$ & $28.38 \pm 10.33 \mathbf{a}$ & $24.13 \pm 4.80 \mathbf{a}$ & $24.02 \pm 3.07 \mathbf{a}$ & $15.30 \pm 4.47 \mathbf{a}$ & $19.78 \pm 7.15 \mathbf{a}$ \\
Iron & $108.02 \pm 51.55 \mathbf{a}$ & $65.93 \pm 33.68 \mathbf{b}$ & $55.39 \pm 10.06 \mathbf{b}$ & $37.33 \pm 9.20 \mathbf{b}$ & $66.50 \pm 28.10 \mathbf{b}$ & $53.37 \pm 11.41 \mathbf{b}$ & $57.63 \pm 18.92 \mathbf{b}$ \\
Lead & $3.92 \pm 2.35 \mathbf{a}$ & $5.98 \pm 4.50 \mathbf{a}$ & $2.75 \pm 0.59 \mathbf{a}$ & $2.65 \pm 1.36 \mathbf{a}$ & $2.35 \pm 0.41 \mathbf{a}$ & $2.97 \pm 1.18 \mathbf{a}$ & $3.17 \pm 0.84 \mathbf{a}$ \\
\hline
\end{tabular}

Note: Unequal letters in horizontal form, show that there are significant statistical differences between mean concentrations ( $\mathrm{p} \geq 0.05)$.

\subsection{Heavy metals in muscle}

The mean concentration of heavy metals in trout muscles (Table 3), showed notable variations among production centers. For copper, the lowest concentration was found at CP6 and the highest at $\mathrm{CP} 1$, with values of $0.14 \pm 0.06$ and $1.81 \pm 0.86 \mu \mathrm{g} / \mathrm{g}$, respectively, with significant statistical differences $(p \geq 0.05)$ between production centers. In the case of zinc, the lowest concentration was observed at CP7 and the highest at CP3, with values of $4.77 \pm 1.80$ and $5.82 \pm 4.80$, respectively, and there were no significant statistical differences $(p \geq 0,05)$ between production centers. For iron, the lowest concentration was found at CP1 and the highest at $\mathrm{CP} 3$, with values of $1.80 \pm 1.59$ and $7.10 \pm 3.99 \mu \mathrm{g} / \mathrm{g}$, respectively, with no statistically significant differences $(p \geq 0.05)$ between production centers. In the case of lead, the lowest concentration was observed at CP1 and the highest at CP3, with values of $0.54 \pm 0.12$ and 
$4.74 \pm 3.82 \mu \mathrm{g} / \mathrm{g}$, respectively, with significant statistical differences $(\mathrm{p} \geq 0.05)$ between production centers.

Concerning the accumulation of heavy metals in muscle, this tissue concentrated mostly zinc, followed by iron, lead and copper. The results of copper concentrations in muscles found in this research are lower than those reported by Sauval (2000), who found a concentration of $<0.5 \mu \mathrm{g} / \mathrm{g}$ in wet weight for "rainbow trout" (Oncorhynchus mykiss) and other freshwater fish such as "pejerrey bonaerense" (Odontesthes bonariensis), common carp (Cyprinus carpio), perch bocona (Percichthys colhuapiensis), periquita (Percichthys altispinnis) and "catfish otuno" (Diplomystes viedmensis). Argota Coelho et al. (2005) who, working with biological matrices, found a concentration of $3 \mu \mathrm{g} / \mathrm{g}$ for the total mass of fish.

Regarding zinc, the results obtained in this work are higher than those found by Sauval (2000) in the muscle of "rainbow trout", which showed a concentration of $3.3 \mu \mathrm{g} / \mathrm{g}$, and, in other freshwater fish such as "pejerrey", $4.7 \mu \mathrm{g} / \mathrm{g}$, in "common carp", $4.4 \mu \mathrm{g} / \mathrm{g}$, in "perch", $3.1 \mu \mathrm{g} / \mathrm{g}$, and in "periquita", $5.1 \mu \mathrm{g} / \mathrm{g}$ in wet weight. Argota Coelho et al. (2005), working with biological matrices, found a concentration of $42 \mu \mathrm{g} / \mathrm{g}$ for the total mass of fish.

As for iron, the results found in this research are higher (except for CP1 and CP6) than those found by Sauval (2000), which report a content of $3.1 \mu \mathrm{g} / \mathrm{g}$ for "rainbow trout" muscle. Other freshwater fish showed the following concentrations: "pejerrey bonaerense", $1.0 \mu \mathrm{g} / \mathrm{g}$; "common carp", $5.4 \mu \mathrm{g} / \mathrm{g}$; "perca bocona", $4.8 \mu \mathrm{g} / \mathrm{g}$; "parakeet", $3.5 \mu \mathrm{g} / \mathrm{g}$; and "catfish Otum ", $5.4 \mu \mathrm{g} / \mathrm{g}$ by wet weight. Argota Coelho et al. (2005), working with biological matrices, found a concentration of $31.3 \mu \mathrm{g} / \mathrm{g}$ for the total mass of fish.

For lead, the concentrations obtained are very high compared with those found by Sauval (2000), who reported a concentration $<0.15 \mu \mathrm{g} / \mathrm{g}$, in wet weight, for "rainbow trout" muscles and for other freshwater fish Such as "pejerrey bonaerense", "common carp", "perca bocona", "periquita" and "catfish otuno".

In this study, very high levels of lead were found in muscles, far exceeding the permissible maximum limit (PML) established by the European Union, which is $0.3 \mu \mathrm{g} / \mathrm{g}$ for fish meat and by the Mexican official standard, NOM-027-SSAI-1993, which is $1.0 \mu \mathrm{g} / \mathrm{g}$ for fresh, chilled and frozen fishery products.

The concentrations of copper, zinc, iron and lead registered in livers, kidneys and muscles of trout was high, and in the specific case of lead in muscles, the content exceeded the maximum limits established by current international legislation. This is possibly due to the mining and metallurgical companies, which discharge their effluents into the waters that are used in the intensive production of trout without any treatment. Consequently, the concentration of heavy metals in the water increases, and the metals become concentrated in the tissues of fish through the process of bioaccumulation.

Table 3. Mean concentration of heavy metals in trout muscles.

\begin{tabular}{lccccccc}
\hline $\begin{array}{l}\text { Metals } \\
(\mu \mathrm{g} / \mathrm{g} \text { Wet } \\
\text { weigh) }\end{array}$ & CP1 & CP2 & CP3 & CP4 & CP5 & CP6 & CP7 \\
\cline { 2 - 7 } Copper & $1.81 \pm 0.86 \mathbf{a}$ & $1.07 \pm 1.37 \mathbf{a}$ & $0.39 \pm 0.28 \mathbf{a}$ & $0.42 \pm 0.39 \mathbf{a}$ & $0.32 \pm 0.24 \mathbf{a}$ & $0.14 \pm 0.06 \mathbf{b}$ & $0.33 \pm 0.08 \mathbf{a}$ \\
& & & & & & \\
Zinc & $5.55 \pm 2.78 \mathbf{a}$ & $5.60 \pm 4.00 \mathbf{a}$ & $5.82 \pm 4.80 \mathbf{a}$ & $5.33 \pm 2.57 \mathbf{a}$ & $5.20 \pm 2.12 \mathbf{a}$ & $5.23 \pm 2.49 \mathbf{a}$ & $4.77 \pm 1.80 \mathbf{a}$ \\
& $1.80 \pm 1.59 \mathbf{a}$ & $4.63 \pm 1.76 \mathbf{a}$ & $7.10 \pm 3.99 \mathbf{a}$ & $3.38 \pm 0.20 \mathbf{a}$ & $4.53 \pm 0.65 \mathbf{a}$ & $2.66 \pm 1.90 \mathbf{a}$ & $4.40 \pm 0.83 \mathbf{a}$ \\
Iron & $0.54 \pm 0.12 \mathbf{b}$ & $1.21 \pm 0.43 \mathbf{a}$ & $4.74 \pm 3.82 \mathbf{a}$ & $1.88 \pm 1.21 \mathbf{a}$ & $0.72 \pm 0.22 \mathbf{a}$ & $1.09 \pm 0.59 \mathbf{a}$ & $0.82 \pm 0.23 \mathbf{a}$ \\
\hline
\end{tabular}

Note: Unequal letters in horizontal form, show that there are significant statistical differences between mean concentrations $(\mathrm{p} \geq 0.05)$. 
Comparing the mean levels of lead in trout muscles, the registered values exceeded the PML established by EU Regulation (CE) $\mathrm{N}^{\circ} 1881 / 2006$ for fish meat $(0.3 \mu \mathrm{g} / \mathrm{g})$. In CP1, 1.8; CP2, 4.03; CP3, 15.8; CP4' 6.27; CP5, 2.4; CP6, 3.63 and CP7, 2.73 times, respectively. Likewise, the registered values exceeded the PML of the Mexican official standard, NOM-027-SSA1-1993, for fresh, chilled and frozen fish products $(1.0 \mu \mathrm{g} / \mathrm{g}): \mathrm{CP} 2,1.21$; CP4, 4.74; CP4, 1.88 and CP6, 1.09 times, respectively. Production centers CP1, CP5 and CP7 did not exceed the PML (Figure 2).

\section{$\mu \mathrm{g} / \mathrm{g}$}

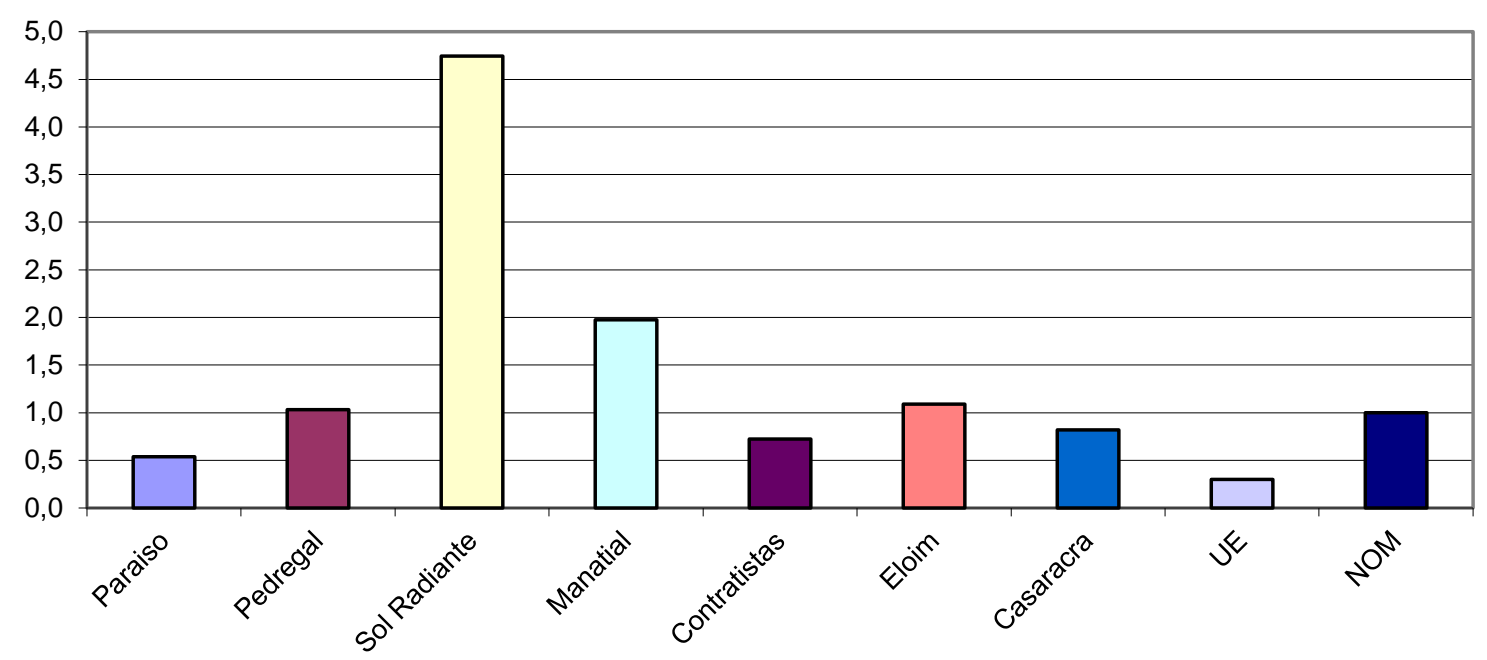

Figure 2. Comparison of the mean concentrations of lead in trout muscles and PML of UE and NOM for fish meat.

\subsection{Concentration of heavy metals in water used for the production of trout}

Little is known about the level of pollutants in water used for the production of trout for export in the central highlands of the Peruvian Mantaro River Watershed, which is greatly influenced by the mining and metallurgical industries. Nevertheless, in the last two decades the Peruvian government has promoted the farming of fish for export purposes in this part of Peru.

The results obtained show significant levels of copper, zinc, iron and lead in the water used by the production centers included in the study compared with the levels reported by MINAM (Peru, 2008) for waters from rivers in this watershed. This reveals the strong anthropogenic pressure that these aquatic ecosystems are undergoing. These results are supported by Rizzo et al. (2010), who reported that heavy metals that exceed the normal concentration threshold become potentially toxic. However, even low concentrations of metals can threaten the health of aquatic and terrestrial organisms, including man (Sarmiento et al., 2011).

The toxicity of heavy metals also depends on environmental factors such as temperature, dissolved oxygen and water $\mathrm{pH}$. In the study, the behavior of the physical-chemical factors of water was similar in the Huari and Tishgo Rivers (Table 4). However, the highest temperature and $\mathrm{pH}$ value was recorded at the CP6 production center and the highest dissolved oxygen at the CP7 production plant. 
In aquatic environments, $\mathrm{pH}$ facilitates the bioavailability and toxicity of most of these metals by affecting the balance between metal speciation, complexation, solubility and ion exchange (Janssen, 2003). In fish, these factors favor the bioavailability of heavy metals during the gill respiration process (De Schamphelaere and Janssen, 2004). The alkaline pH values registered in the water of fish production centers suggest that heavy metals are less available. However, $\mathrm{Hg} \mathrm{Cd}$ and $\mathrm{Pb}$ that exceeded the maximum permissible limits in water for human consumption are possibly associated with particles suspended from the water, which, like As, Mo, Se and Cr, tend to be less available at alkaline pH (Manzione and Merrill, 1989).

Table 4. Physicochemical factors of water.

\begin{tabular}{llccc}
\hline $\begin{array}{c}\text { Production } \\
\text { Center }\end{array}$ & River & $\begin{array}{c}\text { Temperature } \\
\left({ }^{\circ} \mathrm{C}\right)\end{array}$ & $\begin{array}{c}\text { Dissolved oxygen } \\
(\mathrm{ppm})\end{array}$ & $\mathrm{pH}$ \\
\hline CP1 & Huari & 10.3 & 7.6 & 7.86 \\
CP2 & Huari & 10.4 & 7.4 & 7.79 \\
CP3 & Tishgo & 11.2 & 7.8 & 7.93 \\
CP4 & Tishgo & 11.0 & 7.8 & 8.09 \\
CP5 & Tishgo & 11.3 & 7.7 & 8.14 \\
CP6 & Tishgo & 11.6 & 7.9 & 8.25 \\
CP7 & Tishgo & 10.4 & 8.1 & 8.03 \\
\hline
\end{tabular}

Regarding copper concentration, the results showed a similar concentration behavior in six fish production centers, elevated only in the CP5 production center, at $0.0399 \mathrm{mg} / \mathrm{L}$, a result that is higher than those reported by MINSA (Peru, 2006) for the Huari River, with copper concentrations ranging from $<0.005$ to $0.022 \mathrm{mg} / \mathrm{L}$, and for the Tishgo River, with concentrations of $0.005 \mathrm{mg} / \mathrm{L}$. These results agree with some studies carried out in the rivers of northern Peru, which present similar environmental and anthropogenic characteristics (Huaranga et al., 2012). The highest average concentration of copper was registered at the CP4 production center, at $0.0515 \mathrm{mg} / \mathrm{L}$. The values above this concentration become toxic to fish and other aquatic organisms, even more so if they act synergistically with zinc (Lombardi et al., 2010; Sakulsak, 2012) (Table 5).

The mean concentrations of copper, with the exception of CP5, exceeded the environmental quality standard (EQS) for river water in the sierra, established by the Ministry of the Environment of Peru, which is $0.02 \mathrm{mg} / \mathrm{L}$ (Peru, 2008), and the standard of quality for aquatic life in freshwater of the US Environmental Protection Agency (USEPA, 1994), which is $0.012 \mathrm{mg} / \mathrm{L}$, and the standard for copper in surface water of the World Health Organization (WHO), which is $0.003 \mathrm{mg} / \mathrm{L}$ (Pittaluga and Suvires, 2006) (Figure 3). However, they did not exceed the quality standard of water for trout farming of the European Union, which states that the maximum total copper concentration should not exceed $0.1 \mathrm{mg} / \mathrm{L}$, nor the quality standard for fish and trout farming of $<0.3 \mathrm{mg} / \mathrm{L}$ reported by Klontz (1991).

The mean concentration of zinc in all production centers under study exceeded the EQS for the rivers of the highlands, established by MINAM, which is $0.03 \mathrm{mg} / \mathrm{L}$ (Peru, 2008), the quality standard for aquatic life in fresh water of the US EPA, which is $0.032 \mathrm{mg} / \mathrm{L}$, the standard for zinc surface in surface water of WHO, which is $0.02 \mathrm{mg} / \mathrm{L}$ (Pittaluga and Suvires, 2006) (Figure 4), and the quality standard for the fish and trout farming reported by Klontz (1991) for fish and trout farming, which is $<0.04 \mathrm{mg} / \mathrm{L}$. 
$\mathrm{mg} / \mathrm{L}$

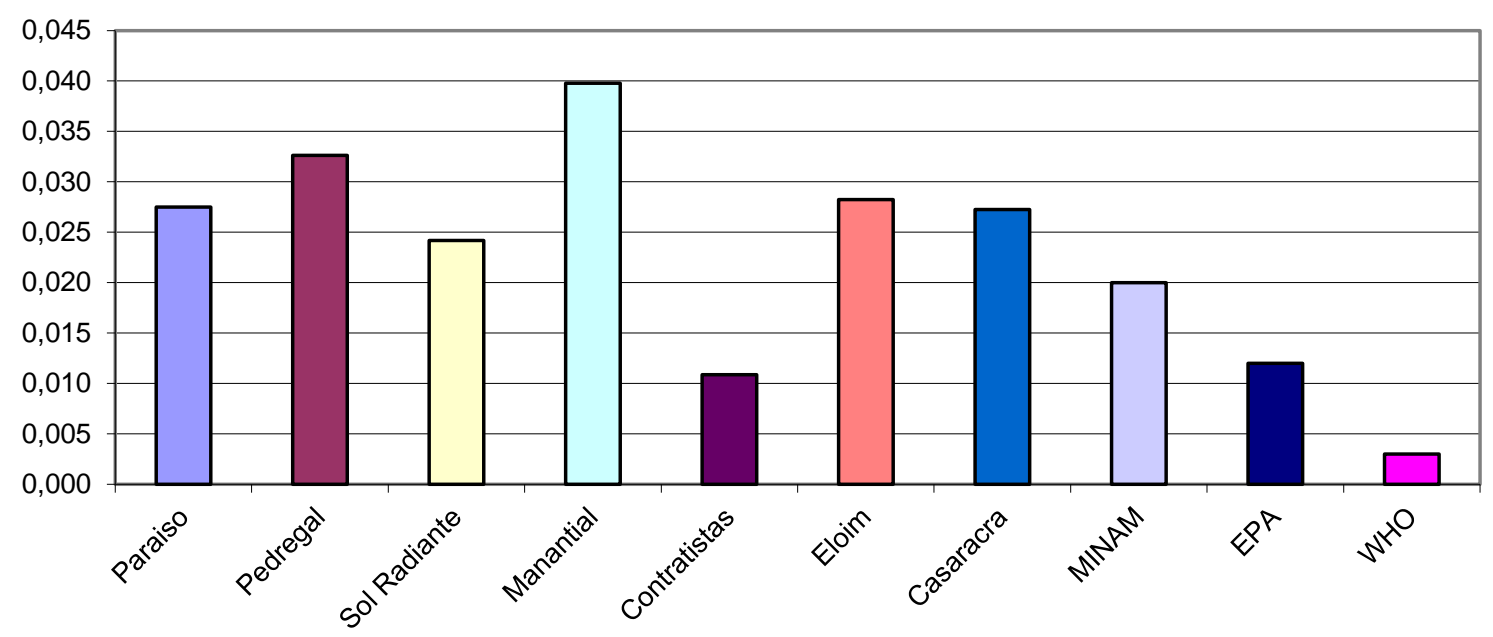

Figure 3. Comparison of the mean concentration of total copper of water with EQS of MINAM and PML of the EPA and WHO.

mg/L

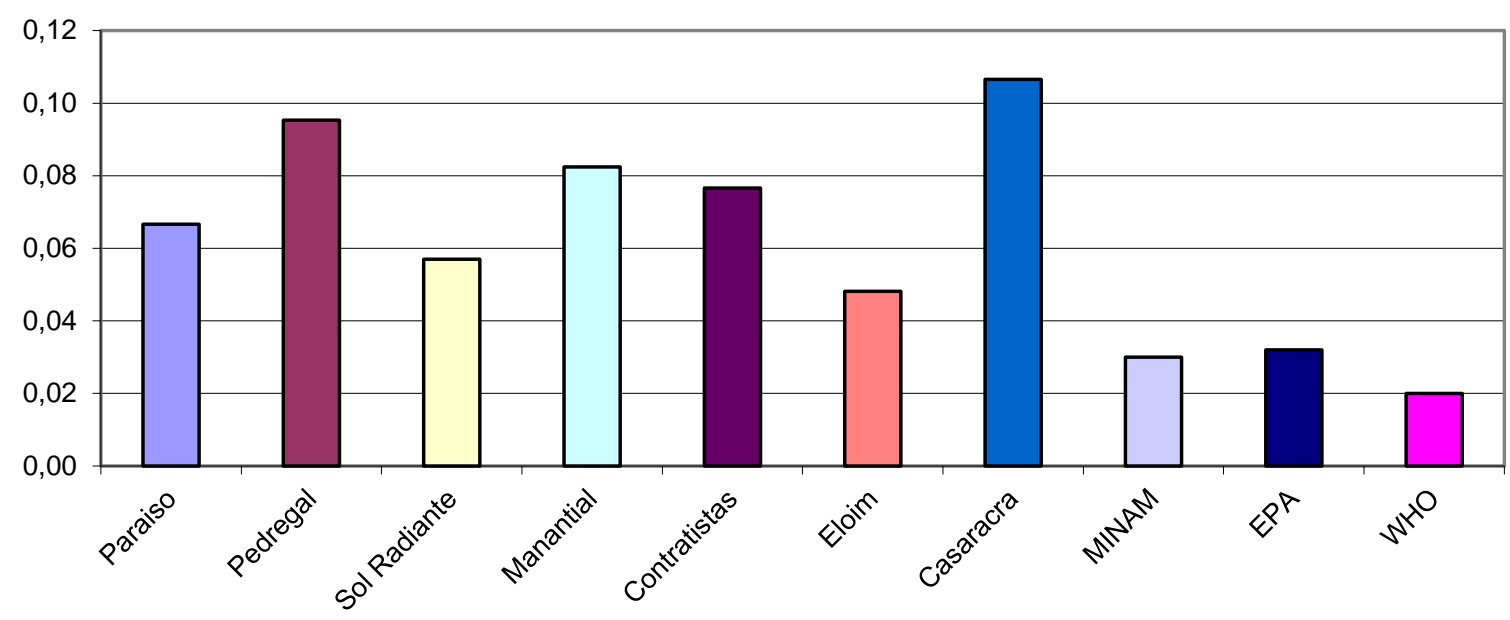

Figure 4. Comparison of the mean concentration of total zinc in water with EQS of MINAM and PML of the EPA and WHO.

Studies conducted by MINSA (Peru, 2006) in Yauli-Junín reported concentrations of zinc from $<0.052$ to $0.308 \mathrm{mg} / \mathrm{L}$ for the Huari River and concentrations of $<0.087$ to $0.179 \mathrm{mg} / \mathrm{L}$ for the Tishgo River. There are studies carried out in other countries at similar altitudes, such as Pittaluga and Suvires (2006), which reported a zinc concentration of $0.001 \mathrm{mg} / \mathrm{L}$, and Alcalde et al. (2000), which report a Zinc concentration of $0.02 \mathrm{mg} / \mathrm{L}$ for the Colorado River. These results are much lower than those found in this research. 
Pérez et al. (2002), who studied the pollution of the Copper River, reported a zinc concentration from 0.010 to $1.040 \mathrm{mg} / \mathrm{L}$, and Gómez-Álvarez et al. (2004) reported a zinc concentration from 0.03 to $2.45 \mathrm{mg} / \mathrm{L}$ for surface water of the San Pedro River; these results are higher than those found in this work.

The concentration levels for iron did not exceed the quality standard reported by Klontz (1991), which is $<1.0 \mathrm{mg} / \mathrm{L}$ for fish and trout farming. They did not reach lethal levels, since according to Garcia (2002), concentrations of $0.9 \mathrm{mg} / \mathrm{L}$ and $\mathrm{pH} 6.5$ - 7.5 lead to the death of fish.

This study found higher results than those reported by MINSA (Peru, 2006) in Yauli-Junín, which found iron concentrations of $<0.164$ to $0.2759 \mathrm{mg} / \mathrm{L}$ for the Huari River and of $<0.289$ to $0.681 \mathrm{mg} / \mathrm{L}$ for the Tishgo River. But the results are low in relation to those found by Pérez et al. (2002), who reported a high iron concentration from 0.001 to $0.25 \mathrm{mg} / \mathrm{L}$ in Copper River water, and by Gómez-Álvarez et al. (2004) who reported a high iron concentration of 0.26 to $15.23 \mathrm{mg} / \mathrm{L}$ for the San Pedro River.

The mean concentrations of lead exceeded the EQS, established by the MINAM for the rivers of the Peruvian highlands, which is $0.001 \mathrm{mg} / \mathrm{L}$ (Peru, 2008)), the standard of quality for aquatic life in fresh water of the US EPA, which is $0.0032 \mathrm{mg} / \mathrm{L}$, the standard for lead in surface water of WHO, which is $0.003 \mathrm{mg} / \mathrm{L}$ (Pittaluga and Suvires, 2006) and that of the EU for trout farming, which is $0.03 \mathrm{mg} / \mathrm{L}$. The exception was CP7, which in this case did not reach lethal levels (Figure 5).

\section{mg/L}

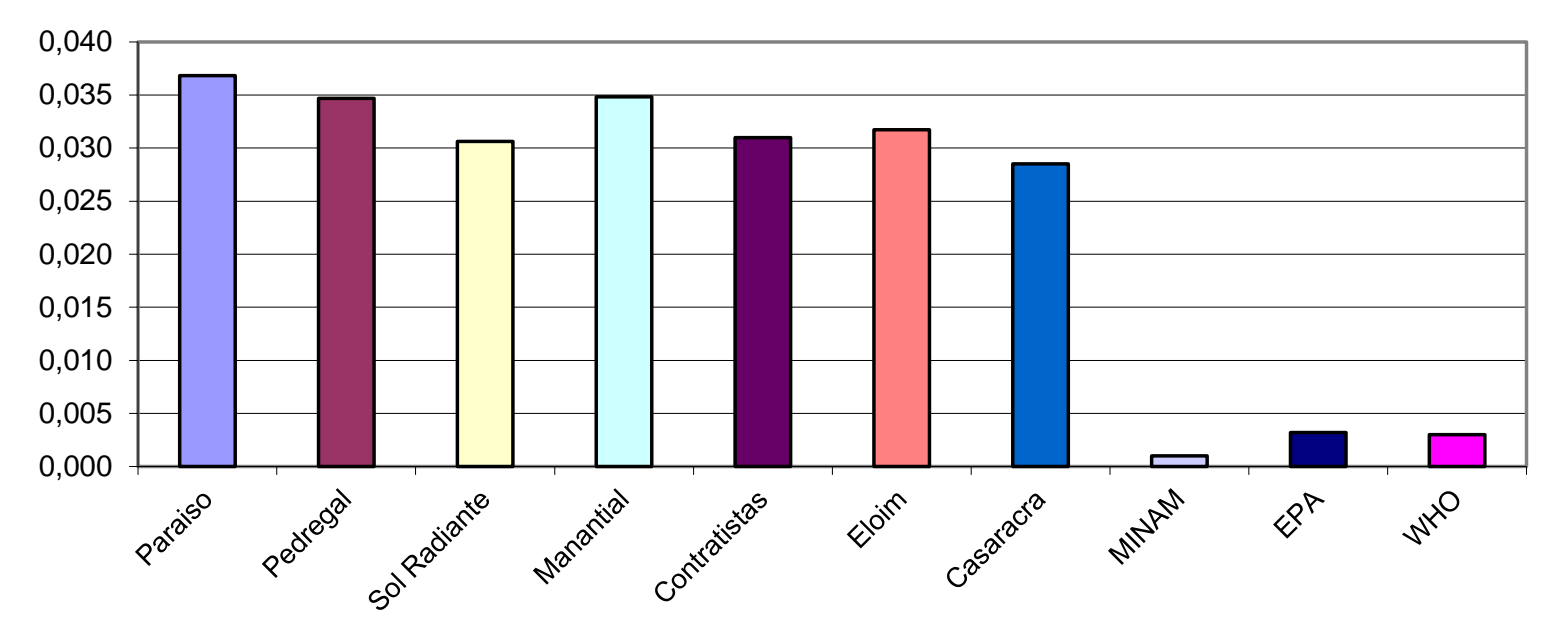

Figure 5. Comparison of the mean concentration of total lead of water with EQS del MINAM y PML de la EPA y WHO.

The results of lead concentrations found in this study are higher than those reported by MINSA (Peru, 2006) in Yauli-Junín, which found that lead concentrations ranged from 0.025 to $0.079 \mathrm{mg} / \mathrm{L}$ in the Huari River and concentrations of $<0.025 \mathrm{mg} / \mathrm{L}$ for the Tishgo River. Pitaluga and Suvires (2006) found a variation in lead concentration from 0.001 to $0.012 \mathrm{mg} / \mathrm{L}$ in the Castaño River and Alcalde et al. (2000) found a lead concentration of $0.007 \mathrm{mg} / \mathrm{L}$ in the Colorado River. However, the results of the study are lower than those found by Gómez-Álvarez et al. (2004), who reported concentrations ranging from below the detection limit to $0.3 \mathrm{mg} / \mathrm{L}$ in the water of the San Pedro River. 
Table 5. Mean concentration of total heavy metals in water.

\begin{tabular}{|c|c|c|c|c|c|c|c|}
\hline \multirow{2}{*}{$\begin{array}{l}\text { Metals } \\
\text { (mg/L) }\end{array}$} & \multicolumn{7}{|c|}{ Production centers } \\
\hline & CP1 & $\mathrm{CP} 2$ & CP3 & CP4 & CP5 & CP6 & CP7 \\
\hline Copper & $0.0275 \pm 0.0422 \mathbf{a}$ & $0.0326 \pm 0.0361 \mathrm{a}$ & $0.0242 \pm 0.0438 \mathbf{a}$ & $0.0399 \pm 0.0515 \mathbf{a}$ & $0.0109 \pm 0.0131 \mathrm{a}$ & $0.0282 \pm 0.0420 \mathbf{a}$ & $0.0273 \pm 0.0383 \mathbf{a}$ \\
\hline Zinc & $0.0666 \pm 0.0258 \mathbf{a}$ & $0.0953 \pm 0.0494 \mathbf{a}$ & $0.0570 \pm 0.0236 \mathbf{a}$ & $0.0824 \pm 0.0410 \mathbf{a}$ & $0.0766 \pm 0.0357 \mathbf{a}$ & $0.0481 \pm 0.0200 \mathbf{a}$ & $0.1064 \pm 0.0938 \mathbf{a}$ \\
\hline Iron & $0.1359 \pm 0.0925 \mathbf{a}$ & $0.1288 \pm 0.0640 \mathbf{a}$ & $0.1163 \pm 0.1361 \mathbf{a}$ & $0.1109 \pm 0.0615 \mathbf{a}$ & $0.0977 \pm 0.0486 \mathbf{a}$ & $0.0773 \pm 0.0562 \mathbf{a}$ & $0.1060 \pm 0.0902 \mathbf{a}$ \\
\hline Lead & $0.0368 \pm 0.0241 \mathbf{a}$ & $0.0347 \pm 0.0113 \mathbf{a}$ & $0.0306 \pm 0.0202 \mathbf{a}$ & $0.0347 \pm 0.0089 \mathbf{a}$ & $0.0310 \pm 0.0098 \mathbf{a}$ & $0.0317 \pm 0.0181 \mathbf{a}$ & $0.0285 \pm 0.0156 \mathbf{a}$ \\
\hline
\end{tabular}

Note: Unequal letters in horizontal form show that there are significant statistical differences between mean concentrations $(\mathrm{p} \geq 0.05)$.

The correlation analysis between water metals and trout tissues at a significance level of 0.05 showed a low and non-significant correlation between the concentration levels of copper, zinc, iron and lead in the water and the concentration levels of these metals in the livers, kidneys and muscles, with the exception of copper, which had a significant correlation (Table 6).

Table 6. Correlation coefficients between the concentration level of heavy metals of water and trout tissues.

\begin{tabular}{lccc}
\hline \multirow{2}{*}{ Heavy metals of water } & \multicolumn{3}{c}{ Trout tissues } \\
\cline { 2 - 4 } Copper & Livers & Kidneys & Muscles \\
Zinc & 0.179 n.s. & 0.024 n.s. & $0.389 *$ \\
Iron & 0.018 n.s. & 0.236 n.s. & 0.047 n.s. \\
Lead & 0.183 n.s. & 0.276 n.s. & 0.01 n.s. \\
\hline
\end{tabular}

$*=$ Significant $(\mathrm{p} \leq 0,05)$.

n.s. $=$ Non-significant.

\section{CONCLUSIONS}

The greatest bioaccumulation of heavy metals in the trout tissues of the Yauli-Junín production centers occurs in livers, followed by kidneys and is much smaller in muscles.

The metal that bioaccumulates most in the livers is iron, followed by zinc, copper and lead. The metal that bioaccumulates most in the kidneys is iron, followed by zinc, lead and copper. The metal that most bioaccumulates in the muscles is zinc, followed by iron, lead and copper.

The concentration levels of copper, zinc, iron and lead in the livers followed the same pattern of accumulation ( $\mathrm{Fe}>\mathrm{Zn}>\mathrm{Pb}>\mathrm{Cu}$ ) obtained by other authors for rainbow trout and other fish in natural environments. The kidneys and muscles did not follow the same pattern of accumulation.

The concentrations of copper, zinc, iron and lead in the muscles, is greater than the results obtained by other authors for rainbow trout and other fish.

The concentrations of lead in muscles exceeded the maximum allowable limit established by EU Regulation (CE) N. 1881/2006 for the meat of fish in all production centers and by the Mexican official standard NOM-0127-SSA1-1993 for fresh, chilled and frozen fishery products, with the exception of Paraíso, Contratistas Véliz, and Casaracra-UNCP. 
The concentrations of copper, zinc iron and lead in the waters of the Yauli-Junín trout production centers exceeded national environmental quality standards for water established by the Ministry of the Environment of Peru for the rivers of the coast and highlands.

The lead concentrations were higher than the maximum permissible limit established by the European Union for trout farming.

The correlation between the concentrations of copper, zinc, iron and lead in water and the concentrations of these metals in the livers, kidneys and muscles, is low and not significant, except for copper, which had a significant and average correlation.

\section{REFERENCES}

AGAH, H.; LEEMAKERS, M.; ELSKENS, M.; FATEMI, S. M. R.; BAEYENS, W. Accumulation of trace metals in the muscles and liver tissues of five fish species from the Persian Gulf. Environmental Monitoring Assessment, v. 157, p. 499-514, 2009. http://dx.doi.org/10.1007/s10661-008-0551-8

ALCALDE, R.; PERL, J. E.; ANDRÉS, F. Calidad del ambiente acuático en el sistema de río Colorado. In: Informe de campaña de muestreo de agua. Buenos Aires, 2000. p. 2037.

AMERICAN PUBLIC HEALTH ASSOCIATION - APHA. Part 3000, Metals. In: Standard methods for the examination of water and wastewater. $22^{\text {nd }} e d$. Washington, D.C., 2012. p. 3.1-3.106.

ARGOTA COELHO, H.; SÁNCHEZ GONZÁLEZ, M.; ARGOTA PÉREZ, G. Determinación de metales pesados en matrices biológicas. Revista Cubana de Química, v. 27, n. 1, p. 14, 2005.

BANDOWE, B. A. M.; BIGALKE, M.; BOAMAH, L.; NYARKO, E.; SAALIA, F. K.; WILCKE, W. Polycyclic aromatic compounds (PAHs and oxygenated PAHs) and trace metals in fish species from Ghana (West Africa): Bioaccumulation and health risk assessment. Environment International, v. 65, p. 135-146, 2014. https://doi.org/10.1016/j.envint.2013.12.018

CANLI, M.; ATLI, G. The relationships between heavy metal (Cd, $\mathrm{Cr}, \mathrm{Cu}, \mathrm{Fe}, \mathrm{Pb}, \mathrm{Zn}$ ) levels and the size of six Mediterranean fish species. Environmental Pollution, v. 121, n. 1, p. 129-136, 2003. https://doi.org/10.1016/S0269-7491(02)00194-X

CLIFFORD, B. R.; TAYLOR, R. A. Bioestadística. 1. ed. México: Pearson Educación, 2008. $538 \mathrm{p}$.

CUÉLLAR CARRASCO, L. Contaminación, animales acuáticos y acuicultura. Anales de la Real Academia de Ciencias Veterinarias, v. 8, n. 8, p. 291-314, 2000.

DE SCHAMPHELAERE, K. A.; JANSSEN, C. R. Bioavailability and Chronic Toxicity of Zinc to Juvenile Rainbow Trout (Oncorhynchus mykiss): Comparison with Other Fish Species and Development of a Biotic Ligand Model. Environmental Science \& Technology, v. 38, n. 23, p. 6201-6209, 2004. http://dx.doi.org/10.1021/es049720m

DEMIRAK, A.; YILMAZ, F.; TUNA, L. A.; OZDEMIR, N. Heavy metals in water, sediment and tissues of Leuciscus cephalusfrom a stream in southwestern Turkey. Chemosphere, v. 63, p. 1451-1458, 2006. https://doi.org/10.1016/j.chemosphere.2005.09.033 
DUDGEON, D. A.; ARTHINGTON, H.; GESSNER, M. O.; KAWABATA, Z-I.; KNOWLER, D. J.; LÉVÊQUE, C. et al. Freshwater biodiversity: importance, threats, status and conservation challenges. Biological Reviews, v. 81, p. 163-182, 2006. http://dx.doi.org/10.1017/S1464793105006950

DYBERN, B. B.; DALZIEL, C.; JANSSON, J.; JENSEN, B.; REUTERGARDH, S. Análisis de presencia de metales y organoclorados en los peces. Roma: FAO, 1983. p. 1-14. (Manual de Métodos de Investigación del Medio Ambiente Acuático, 212).

GAMMONS, C. H.; SLOTTON, D. G.; GERBRANDT, B.; WEIGHT, W.; YOUNG, C. A.; McNEARNY, R. L. et al. Mercury concentration of fish, river water, and sediment in the Río Ramis-Lake Titicaca watershed, Peru. Science of the Total Environmental, v. 368, p. 637-648, 2006. https://doi.org/10.1016/j.scitotenv.2005.09.076

GARCÍA CAMBERO, J. Estado actual de la contaminación por metales pesados y pesticidas organoclorados en el parque natural de Monfragüe. 2002. Memoria (Grado de Doctor) - Facultad de Veterinaria, Universidad de Extremadura, Extremadura, 2002.

GÓMEZ-ÁlVAREZ, A.; VILLALBA-ATONDO, A.; ACOSTA-RUÍZ, G.; CASTAÑEDAOLIVARES, M.; KAMP, D. Metales pesados en el agua superficial del río San Pedro, durante los años 1997 y 1999. Revista Internacional de Contaminación Ambiental, v. 1, n. 1, p. 1-8, 2004.

HUARANGA, M. F.; MÉNDEZ, G. E.; QUILCAT, L. V.; HUARANGA, A. F. Pollution by heavy metals in the Moche River Basin, 1980 - 2010, La Libertad - Peru. Scientia Agropecuaria, n. 3, p 235-247, 2012.

http://dx.doi.org/10.17268/sci.agropecu.2012.03.05

HURTADO. J.; GONZÁLES, G. F.; STEENLAND, K. Mercury exposures in informal gold miners and relatives in southern Peru. International Journal of Occupational Environmental Health, v. 12, n. 4, p. 340-345, 2006.

JANSSEN, C. R.; HEIJERICK, D. G.; DE SCHAMPHELAERE, K. A. C.; ALLEN, H. E. JEZIERSKA, B.; WITESKA, M. Environmental risk assessment of metals: tools for incorporating bioavailability. Environment International, v. 28, n. 8, p. 793-800, 2003. https://doi.org/10.1016/S0160-4120(02)00126-5

JEZIERSKA, B.; WITESKA, M. The Metal Uptake and Accumulation in Fish Living in Polluted Waters. In: TWARDOWSKA, I.; ALLEN, H. E.; HÄGGBLOM, M. M.; STEFANIAK, S. (Eds.). Soil and Water Pollution Monitoring, Protection and remediation. Dordrecht: Springer, 2006. p. 107-114.

JIMÉNEZ, R.; DÍAZ, C.; POMARES, M.; ALLEYNE, S.; TORRES, I.; AGUILAR, C. Procedimiento analítico para la determinación de metales en tejido de peces (Micropogonias furnieri) por espectroscopía atómica. Nueva Revista Cubana Química, v. 12, n. 1, p. 32-41, 2000.

KEHRIG, H. A.; FERNANDES, K. W. G.; MALM, O.; SEIXAS, T. G.; DI BENEDITTO, A. P. M.; SOUZA, C. M. M. Transferência trófica de mercúrio e selênio na costa norte do Rio de Janeiro. Química Nova, v. 32, p. 1822-1828, 2009.

KLONTZ, G. Manual for rainbow trout production on the family-owned. Moscow: Department of Fish and Wildlife Resources, University of Idaho, 1991. 
KOJADINOVIC, J.; POTIER, M.; LE CORRE, M.; COSSON, R. P.; BUSTAMANTE, P. Bioaccumulation of trace elements in pelagic fish from the Western Indian Ocean. Environmental Pollution, v. 146, p. 548-66, 2007. https://doi.org/10. 1016/j.envpol.2006.07.015

LAJEUNESSE, A.; GAGNON, C.; GAGNÉ, F.; LOUIS, S.; CEJKA, P.; SAUVÉ, S. Distribution of antidepressants and their metabolites in brook trout exposed to municipal wastewaters before and after ozone treatment - evidence of biological effects. Chemosphere, v. 83, p. 564-571, 2011. https://doi.org/10.1016/j.chemosphere. 2010.12.026

LOMBARDI, P. E.; PERI, S. I.; VERRENGIA, G. N. Trace metal levels in Prochilodus lineatus Collected from the La Plata River, Argentina. Environmental Monitoring and assessment, v. 160, p. 47-59, 2010. http://dx.doi.org/10.1007/s10661-008-0656-0

LOZANO, G.; HERRAIZ, E.; HARDISSON, A.; GUTIÉRREZ, A. J.; GONZÁLEZWELLER, D.; RUBIO, C. Heavy and trace metal concentrations in three rockpool shrimp species (Palaemon elegans, Palaemon adspersus and Palaemon serratus) from Tenerife (Canary Islands). Environmental Monitoring and Assessment, v. 168, p. 451-460, 2010. http://dx.doi.org/10.1007/s10661-009-1126-z

MANZIONE, M. A.; MERRILL, D. T. Trace metal removal by iron coprecipitation: Fiel evaluation: Final report. Report EPRIGS-6438. Palo Alto: Electric Power Research Institute, 1989.

MARTORELL, I.; PERELLÓ, G.; MARTÍ-CID, R.; LLOBET, J. M.; CASTELL, V.; DOMINGO, J. L. Human exposure to arsenic, cadmium, mercury, and lead from foods in Catalonia, Spain: temporal trend. Biological Trace Element Research, v. 14, p. 309322, 2011. http://dx.doi.org/10.1007/s12011-010-8787-x

OLMEDO, P.; PLA, A.; HERNÁNDEZ, A. F.; BARBIER, F.; AYOUNI, L.; GI, F. Determination of toxic elements (mercury, cadmium, lead, tin and arsenic) in fish and shellfish samples. Risk assessment for the consumers. Environment International, v. 59, p. 63-72, 2013. https://doi.org/10.1016/j.envint.2013.05.005

PADILLA, E. Eficiencia de Eichhornia crassipes, Cyperus corimbosus y Scirpus californicus en la acumulación de metales pesados cobre zinc, plomo y hierro. 2005. Tesis (Doctoral) - Escuela de Postgrado, Universidad Nacional de Trujillo, Trujillo, 2005.

PÉREZ, N.; MARAÑÓN, A.; LÓPEZ, C.; PÉREZ, Y.; GONZÁLEZ, A.; CASCARET, D. et al. Contaminación de las aguas del río Cobre en la zona de la mina grande del Cobre. Revista Cubana de Ciências Químicas, v. 14, n. 2, p. 24-33, 2002.

PERU. Ministerio del Ambiente - MINAM. Estándares nacionales de calidad ambiental para agua. Decreto Supremo No 002-2008-MINAM. Anexo I, categoría 4: conservación del ambiente acuático. Lima, 2008.

PERU. Ministerio de Salud - MINSA. Vigilancia de la calidad de los recursos hídricos: río Mantaro y tributarios. Lima, 2006. 18 p.

PIENIAK, Z.; VERBEKE, W.; SCHOLDERER, J. Health-related beliefs and consumer knowledge as determinants of fish consumption. Journal of Human Nutrition and Dietetics, v. 23, p. 480-488, 2010. http://dx.doi.org/10.1111/j.1365-277X.2010.01045.x 
PITTALUGA, M. A.; SUVIRES, G. M. Chemical composition and water quality of de Castaño river, Calingasta, San Juan province, Argentina. Multequina, v. 15, p. 17-26, 2006.

RIZZO, A.; DAGA, R.; ARCAGNI, M.; PÉREZ, C.S.; BUBACH, D.; SÁNCHEZ, R. et al. Concentraciones de metales pesados en distintos compartimentos de lagos andinos de Patagonia Norte. Ecología Austral, v. 20, p. 155-171, 2010.

ROBINSON, J.; AVENANT-OLDEWAGE, A. Chromium, copper, iron and manganese bioaccumulation in some organs and tissues of Oreochromis mossambicus from the lower Olifants River, inside the Kruger National Park. Water S.A., v. 23, n. 4, p. 387 - 403, 1997.

SAKULSAK, N. Metallothionin: an overview on its metal homeostatic regulatión in mammals. International Journal of Morphology, v. 30, n. 3, p. 1007-1012, 2012. http://dx.doi.org/10.4067/S0717-95022012000300039

SARMIENTO, A. M.; DELVALLS, A.; NIETO, J. M.; SALAMANCA, M. J.; CARABALLO, M. A. Toxicity and potential risk assessment of a river polluted by acid mine drainage in the Iberian Pyrite Belt (SW Spain). Science of the Total Environment, v. 409, n. 22, p. 4763-4771. 2011. https://doi.org/10.1016/j.scitotenv.2011.07.043

SAUVAL, R. Investigación de sustancias tóxicas en músculo de peces. Informe de campaña de muestreo de peces, p. 11-15, 2000.

SWANSON, D.; BLOCK, R.: MOUSA, S. A. Omega-3 fatty acids EPA and DHA: health benefits throughout life. Advances in Nutrition, v. 3, p. 1-7, 2012. http://dx.doi.org/10. 3945/an.111.000893

UNITED STATES. Environmental Protect Agency - USEPA. Water Quality Standars HandbooK. $2^{\text {nd }}$ edition. Washington, 1994.

ZENKER, A.; CICERO, M. R.; PRESTINACI, F.; BOTTON, P.; CARERE, M. Bioaccumulation and biomagnification potential of pharmaceuticals with a focus to the aquatic environment. Journal of Environmental Management, v. 133, p. 378-387, 2014. https://doi.org/10.1016/j.jenvman.2013.12.017 